\title{
PENGARUH PENGGUNAAN PACLOBUTRAZOL, KNO 3 DAN ETEFON PADA PEMACUAN PEMBUNGAAN TANAMAN MANGGIS (Garcinia mangostana L.)
}

\author{
The Effect of Paclobutrazol, KNO3 and Ethephon on Inducing Mangosteen \\ (Garcinia mangostana L.) Flowering
}

\author{
Novalia Syafitri, Agus Karyanto, Rugayah*, Setyo Widagdo \\ Jurusan Agroteknologi, Fakultas Pertanian, Universitas Lampung \\ *E-mail korespondensi: rugayah.1961@fp.unila.ac.id
}

\begin{abstract}
ABSTRAK
Manggis (Garcinia mangostana L.) termasuk buah tropis yang berbuah musiman dan merupakan komoditas ekspor unggulan Indonesia. Produksi manggis di Indonesia masih tergolong rendah dan tidak kontinu, karena terdapat beberapa faktor yang mempengaruhi. Salah satunya yaitu sifat biennial bearing pada manggis yaitu satu tahun menghasilkan buah yang tinggi diikuti tahun berikutnya dengan produksi yang sangat rendah. Oleh karena itu perlu dilakukan upaya untuk pemacuan pembungaan manggis di luar musim. Penelitian ini bertujuan untuk mengetahui: (1) pengaruh pemberian Paklobutrazol terhadap pemacuan pembungaan pada tanaman manggis, (2) perbedaan pengaruh antara pemberian $\mathrm{KNO}_{3}$ dan Etefon terrhadap pemacuan pembungaan manggis. Penelitian ini dilaksanakan di Desa Mulangmaya, Kecamatan Kota Agung Timur, Kabupaten Tanggamus, Lampung pada ketinggian $250 \mathrm{~m}$ dpl dari bulan September 2018 - April 2019. Penelitian ini menggunakan Rancangan Acak Kelompok (RAK) dengan faktor tunggal terdiri dari 3 perlakuan yaitu $\mathrm{P}_{1}$ (pupuk kandang 10 $\mathrm{kg} /$ tanaman + NPK Nitrophonska $1 \mathrm{~kg} /$ tanaman, $\mathrm{P}_{2}$ (Paklobutrazol $2 \mathrm{ml} / \mathrm{l}+\mathrm{KNO}_{3} 20 \mathrm{~g} / \mathrm{l}+$ pupuk kandang $10 \mathrm{~kg} /$ tanaman + NPK Nitrophonska $1 \mathrm{~kg} /$ tanaman), dan $\mathrm{P}_{3}$ (Paklobutrazol $2 \mathrm{ml} / \mathrm{l}+$ Etefon 40 $\mathrm{ml} / \mathrm{l}+$ pupuk kandang $10 \mathrm{~kg} / \operatorname{tanaman}+\mathrm{NPK}$ Nitrophonska $1 \mathrm{~kg} / \mathrm{tanaman})$. Data yang diperoleh dianalisis dengan analisis ragam dan dilakukan pemisahan nilai tengah dengan uji orthogonal kontras pada taraf nyata 5\%. Hasil penelitian menunjukkan bahwa perlakuan $\mathrm{P}_{2}\left(\right.$ Paklobutrazol $2 \mathrm{ml} / \mathrm{l}+\mathrm{KNO}_{3}$ $20 \mathrm{~g} / \mathrm{l}+$ pupuk kandang $10 \mathrm{~kg} /$ tanaman + NPK Nitrophonska $1 \mathrm{~kg} /$ tanaman) pada tanaman manggis, mampu memacu pembungaan lebih cepat dengan selisih 12 hari $(8,70 \%)$, dan meningkatkan jumlah buah total per tanaman dengan selisih 41 buah $(38,80 \%)$. Pada perlakuan $\mathrm{P}_{3}$ (Paklobutrazol $2 \mathrm{ml} / \mathrm{l}+$ Etefon $40 \mathrm{ml} / \mathrm{l}+$ pupuk kandang $10 \mathrm{~kg} /$ tanaman + NPK Nitrophonska $1 \mathrm{~kg} /$ tanaman) secara tidak terduga menyebabkan kerontokan daun yang signifikan 3 hari setelah penyemprotan Etefon, dan daundaun baru terbentuk sebulan kemudian.
\end{abstract}

Kata kunci : Etefon, $\mathrm{KNO}_{3}$, Paklobutrazol, pembungaan manggis

\begin{abstract}
Mangosteen (Garcinia mangostana L.) is a tropical plant that bears seasonal fruit and is one of Indonesia's leading export commodity. Mangosteen production in Indonesia is still low and not continuous, because there are several factors that influence it. One of them is the character of biennial bearing in mangosteen one year produce high fruit load followed by a next year of very low production. Therefore it is necessary to induce off season mangosteen flowering. This study aims to determine: (1) the effect of Paklobutrazol on the flowering of mangosteen plants, (2) the effect of adding $\mathrm{KNO}_{3}$ and Etefon on the acceleration of mangosteen flowering. This research was conducted in Mulangmaya Village, Kota Agung Timur District, Tanggamus, Lampung. Regency at an altitude of $250 \mathrm{~m}$ above sea level from September 2018 to April 2019. This research used a Randomized Block Design (RBD) with a single factor consisting of 3 treatments, namely $P_{1}$ ( manure $10 \mathrm{~kg} /$ plant + NPK Nitrophonska 1 $\mathrm{kg} /$ plant, $\mathrm{P}_{2}$ (Paclobutrazol $2 \mathrm{ml} / \mathrm{l}+\mathrm{KNO}_{3} 20 \mathrm{~g} / \mathrm{l}+$ manure $10 \mathrm{~kg} /$ plant $+\mathrm{NPK}$ Nitrophonska 1 $\mathrm{kg} /$ plant $)$, and $P_{3}($ Paclobutrazol $2 \mathrm{ml} / \mathrm{l}+$ Etefon $40 \mathrm{ml} / \mathrm{l}+$ manure $10 \mathrm{~kg} /$ plant $+N P K$ Nitrophonska 1
\end{abstract}


$\mathrm{kg} /$ plant). The data obtained were analyzed by analysis of variance and the mean separation was carried out by orthogonal contrast test at the 5\% significance level. The results showed that the treatment of $\mathrm{P}_{2}$ (Paclobutrazol $2 \mathrm{ml} / \mathrm{l}+\mathrm{KNO}_{3} 20 \mathrm{~g} / \mathrm{l}+$ manure $10 \mathrm{~kg} /$ plant $+\mathrm{NPK}$ Nitrophonska 1 $\mathrm{kg} /$ plant) on mangosteen plants was able to spur flowering faster with a difference of 12 days $(8.70 \%)$, and increased the total number of fruits per plant by a difference of 41 fruit (38.80\%). The $P_{3}$ treatment (Paclobutrazol $2 \mathrm{ml} / \mathrm{l}+$ Etefon $40 \mathrm{ml} / \mathrm{l}+$ manure $10 \mathrm{~kg} /$ plant $+N P K$ Nitrophonska $1 \mathrm{~kg} /$ plant $)$, unexpectedly causing significant leaf drop 3 days after Ethephon spray, and new leaves were formed a month later.

Keywords : Ethephon, $\mathrm{KNO}_{3}$, Paclobutrazol, and mangosteen flowering

\section{PENDAHULUAN}

Manggis (Garcinia mangostana L.) adalah tanaman asli Asia Tenggara dan Indo China dan termasuk tanaman buah tropis yang berbuah musiman. Manggis memiliki rasa yang manis serta asam, dengan daging buah berwarna putih seperti salju dan teksturnya lembut seperti es krim dan manggis diberi julukan sebagai "Queen of Tropical Fruits". Oleh karena itu, manggis merupakan salah satu komoditas ekspor buah-buahan yang memiliki nilai ekonomi yang tinggi (Paramawati, 2010).

Manggis memiliki sifat biennial bearing yaitu sifat berbunga dan berbuah yang tidak stabil yaitu berbuah banyak pada satu tahun (on year) dan berbuah sedikit pada tahun berikutnya (off year) sehingga akan menyebabkan fluktuasi harga dan menyulitkan dalam memenuhi kontinuitas ekspor. Menurut Dennis dan Neilsen (1999), biennial bearing dapat terjadi karena buah muda memproduksi hormon giberelin yang ditranslokasikan ke bagian pucuk vegetatif sehingga pucuk akan tumbuh subur untuk membentuk daun dan tidak membentuk bunga pada tahun berikutnya.

Aplikasi paklobutrazol dapat menyebabkan dormansi tunas generatif (tunas bunga) yang telah terinduksi karena Paklobutrazol meningkatkan biosintesis asam absisat (ABA) (Davies, 1995). Oleh karena itu pemberian Paklobutrazol perlu dikombinasikan dengan zat pemecah dormansi seperti $\mathrm{KNO}_{3}$ dan Etefon untuk mengatasi dormansi tunas generatif.

\section{METODE PENELITIAN}

Penelitian ini dilaksanakan pada bulan September 2018 - April 2019 di kebun manggis petani Desa Mulang Maya, Kota Agung Timur, Tanggamus pada ketinggian $250 \mathrm{~m}$ dpl. Alat dan bahan yang digunakan adalah cangkul,ember, pengaduk, gelas takar, meteran, alat tulis, tali rafia, sprayer, plastik, gunting, kamera, tanaman manggis berumur 20-30 tahun, label, air, pupuk NPK Nitrophoska (15:15:15), pupuk kandang sapi, Paklobutrazol, $\mathrm{KNO}_{3}$, dan Etefon.

\section{Rancangan Percobaan}

Penelitian ini menggunakan Rancangan Acak Kelompok (RAK) dengan 3 perlakuan yaitu $\mathrm{P}_{1}(\mathrm{NPK}+$ pupuk kandang), $\mathrm{P}_{2}$ (Paklobutrazol $+\mathrm{KNO}_{3}+\mathrm{NPK}$ + pupuk kandang) dan $\mathrm{P}_{3}$ (Paklobutrazol + Etefon + NPK + pupuk kandang). Semua perlakuan diulang sebanyak lima kali sehingga terdapat 15 tanaman dan setiap tanaman dipilih 3 cabang yang akan diamati. Total cabang yang diamati berjumlah 45 cabang.

Pemilihan cabang sampel yang diamati yaitu dipilih secara menyebar melingkar dengan karakteristik cabang yang mudah dijangkau \pm 2 meter, kondisi baik dan memiliki cabang 3 seperti garpu. Homogenitas ragam diuji dengan uji Bartlett dan aditivitas data diuji dengan uji Tukey. Selanjutnya data dianalisis sidik ragam dan dilanjutkan dengan uji orthogonal kontras pada taraf $5 \%$. 


\section{Pelaksanaan Penelitian}

Tahapan penelitian dimulai dengan memilih tanaman manggis yang berumur 2030 tahun dengan tinggi rata-rata 15 meter. Pengambilan sampel dilakukan secara acak pada kebun manggis milik petani sebanyak 15 sampel tanaman, setiap sampel tanaman dipilih 3 sampel percabangan dan diberi label untuk diamati.

Sebelum dilaksanakan penelitian pada tanaman manggis dilakukan analisis tanah terlebih dahulu. Data yang diperlukan merupakan data lengkap yang meliputi : $\mathrm{pH}$ tanah, N-total, C-organik, P-tersedia, K-dd, KTK, dan tekstur tanah.

Pada 15 sampel tanaman manggis diberi pupuk kandang sebanyak 10 $\mathrm{kg} /$ tanaman dan pupuk NPK Nitrophoska (15:15:15) sebanyak $1 \mathrm{~kg} /$ tanaman dengan cara ditabur pada lubang yang dibuat melingkari kanopi tanaman sesuai lebar tajuk (jarak $1 \mathrm{~m}$ dari batang pohon).

Kemudian setelah satu bulan perlakuan $\mathrm{P}_{2}$ dan $\mathrm{P}_{3}$ setiap ulangan diberi Paklobutrazol dengan kadar 25\%. Paklobutrazol sebanyak $8 \mathrm{ml}$ dilarutkan dengan air hingga volumenya 1 liter. Larutan tersebut lalu disiramkan pada daerah perakaran tanaman. Setelah satu bulan aplikasi Paklobutrazol, perlakuan $\mathrm{P}_{2}$ diberi $\mathrm{KNO}_{3}$ dengan konsentrasi $20 \mathrm{~g} / \mathrm{L}$, sedangkan perlakuan $\mathrm{P}_{3}$ diberi Etefon dengan konsentrasi $40 \quad \mathrm{ml} / \mathrm{L}$ dengan cara disemprotkan pada tanaman dari tajuk atas dengan menggunakan knapsack sprayer sebanyak $5 \mathrm{~L} /$ tanaman.

\section{Pengamatan}

Pengamatan fase vegetatif dilakukan pada saat tanaman berumur 0 minggu setelah aplikasi (msa), $4 \mathrm{msa}, 21 \mathrm{msa}$, dan $29 \mathrm{msa}$. Sedangkan pengamatan fase generatif dilakukan pada saat 29 minggu setelah aplikasi. Variabel yang diamati dalam penelitian ini adalah penambahan panjang cabang utama, jumlah cabang, jumlah daun, jumlah buku, panjang daun, lebar daun, lingkar pangkal cabang, dan waktu muncul bunga, jumlah buah per cabang sampel, jumlah buah total per tanaman.

\section{HASIL DAN PEMBAHASAN}

Secara umum hasil penelitian ini menunjukkan bahwa pada perlakuan pemberian Etefon $\left(\mathrm{P}_{3}\right)$ tidak dapat dibandingkan dengan $\mathrm{P}_{1}$ (tanpa Paklobutrazol) dan $\mathrm{P}_{2}$ (Paklobutrazol + $\mathrm{KNO}_{3}$ ) khususnya pada fase generatif. Hal tersebut dikarenakan pada perlakuan pemberian Etefon yang diterapkan daun mengalami kerontokan sehingga tidak muncul bunga dan tidak berbuah, semua data bernilai 0 . Tetapi pada fase vegetatif semua perlakuan dapat dibandingkan.

Hasil analisis tanah pada lokasi penelitian menunjukkan bahwa lahan manggis tergolong tanah masam dengan $\mathrm{pH}$ 5,54 dengan kandungan unsur hara dalam kisaran rendah (Tabel 1).

Tabel 1. Hasil analisis tanah di Kebun Manggis Desa Mulangmaya Kota Agung Timur

\begin{tabular}{lcc}
\hline \multicolumn{1}{c}{ Parameter } & $\begin{array}{c}\text { Hasil } \\
\text { analisis }\end{array}$ & Keterangan \\
\hline pH & 5.54 & Masam \\
N-total (\%) & 0.22 & Sedang \\
C-organik (\%) & 1.48 & $\begin{array}{c}\text { Rendah } \\
\text { P-tersedia (ppm) }\end{array}$ \\
& 4.65 & $\begin{array}{c}\text { Sangat } \\
\text { Rendah }\end{array}$ \\
K-dd (me/100g) & 0.22 & Rendah \\
KTK (me/100g) & 9.01 & Rendah \\
Tekstrur (\%) & & \\
Pasir & 56.40 & Lempung \\
& & berpasir \\
Debu & 38.00 & \\
Liat & 5.60 & \\
\hline
\end{tabular}

Hasil penelitian menunjukkan bahwa pemberian Paklobutrazol berpengaruh nyata terhadap beberapa variabel pengamatan (Tabel 2 dan 3). Meskipun kandungan hara rendah namun tanaman manggis masih hidup tetapi produksinya rendah. Menurut Rukmana (1995), tanah yang cocok untuk tanaman manggis yaitu memiliki tekstur lempung berpasir, struktur remah, dengan 
tingkat keasaman $(\mathrm{pH})$ berkisar 5-7 serta kandungan bahan organik tinggi.

Pemberian pupuk organik dan anorganik pada penelitian ini dimaksudkan untuk meningkatkan bahan organik tanah dan untuk mengatasi kekurangan unsur hara di dalam tanah. Salah satu pupuk organik yang digunakan yaitu pupuk dari kotoran sapi dan pupuk anorganik yang digunakan yaitu pupuk NPK Nitrophoska (15:15:15). Menurut Lingga dan Marsono (2011) pupuk kandang berperan dalam peningkatan sifat fisik, kimia, dan biologi tanah. Sifat fisik yaitu merangsang terbentuknya agregat tanah dan meningkatkan permeabilitas serta aerasi tanah. Sifat kimia yaitu dapat menambah unsur hara $\mathrm{P}$ dan $\mathrm{K}$ serta meningkatkan kapasitas tukar kation (KTK) yang berperan dalam tanah sehingga tanaman dapat menyerap unsur hara dan air dengan baik. Sifat biologi yaitu dapat meningkatkan mikrobia dalam jumlah cukup yang berperan dalam proses dekomposisi bahan organik.

\section{Fase Vegetatif}

Hasil penelitian menunjukkan bahwa pemberian Paklobutrazol dapat menghambat pertumbuhan vegetatif di antaranya panjang cabang utama, jumlah cabang, jumlah daun, jumlah buku, panjang daun dan lebar daun. Hasil uji orthogonal kontras menunjukkan bahwa penambahan panjang cabang utama dan jumlah cabang pada perlakuan Paklobutrazol lebih kecil dibandingkan tanpa Paklobutrazol (Gambar 1 dan 2). Menurut Lolaei et al., (2013), Paklobutrazol mampu menghambat biosintesis giberelin sehingga dapat menghambat pertumbuhan vegetatif seperti pemanjangan tunas dan tinggi tanaman. Hasil uji orthogonal kontras menunjukkan bahwa penambahan jumlah daun dan jumlah buku pada perlakuan Paklobutrazol lebih kecil dibandingkan tanpa Paklobutrazol (Gambar 3 dan 4). Hal ini dikarenakan Paklobutrazol dapat menghambat sintesis giberelin. Menurut Lakitan (2011), giberelin dapat merangsang pertumbuhan tanaman secara keseluruhan termasuk daun. Oleh karena itu apabila sintesis giberelin dihambat maka pertumbuhan daun akan terhambat. Hasil penelitian Poerwanto et al. (1997) menunjukkan bahwa Paklobutrazol dapat menghambat pertumbuhan vegetatif dengan menurunkan panjang ruas dan jumlah daun pada tanaman mangga gadung.

Hasil yang serupa juga dijumpai pada penambahan panjang daun dan lebar daun perlakuan Paklobutrazol lebih kecil dibandingkan tanpa Paklobutrazol (Gambar 5 dan 6). Hal ini sesuai hasil penelitian Darmawan (2014), bahwa perlakuan Paklobutrazol $2 \mathrm{~g} /$ pohon dapat memperkecil penambahan luas daun dibandingkan tanpa Paklobutrazol pada tanaman jeruk keprok. Hasil pengamatan penambahan lingkar pangkal cabang pada perlakuan tanpa Paklobutrazol lebih kecil dibandingkan dengan pemberian Paklobutrazol (Gambar 7). Hal ini sesuai dengan hasil penelitian Bowo (2018), bahwa pemberian Paklobutrazol 0,9 $\mathrm{ml} /$ pohon dapat mempertebal batang sehingga diameter batang menjadi lebih besar dibandingkan perlakuan tanpa Paklobutrazol pada tanaman jambu air. Menurut Sakhidin dan Suparto (2011), zat penghambat tumbuh yang berbahan aktif Paklobutrazol memiliki pengaruh mampu menghambat perpanjangan batang, membuat diameter batang menjadi lebih besar dan mampu mencegah kerebahan tanaman. 
Tabel 2. Rekapitulasi hasil uji orthogonal kontras pada variabel fase vegetatif pengaruh penggunaan Paklobutrazol, $\mathrm{KNO}_{3}$, dan Etefon pada pemacuan pembungaan tanaman manggis umur 29 minggu setelah aplikasi.

\begin{tabular}{|c|c|c|c|c|c|c|c|}
\hline \multirow[b]{2}{*}{ Perbandingan } & \multicolumn{7}{|c|}{ Variabel Pengamatan pada Penambahan } \\
\hline & $\begin{array}{c}\text { Panjan } \\
\mathrm{g} \\
\text { Cabang } \\
\text { Utama } \\
\end{array}$ & $\sum_{\text {cabang }}$ & $\sum_{\text {Daun }}$ & $\sum_{\text {Buku }}$ & $\begin{array}{c}\text { Panjan } \\
\text { g } \\
\text { Daun }\end{array}$ & $\begin{array}{l}\text { Lebar } \\
\text { Daun }\end{array}$ & $\begin{array}{l}\text { Lingkar } \\
\text { Pangkal } \\
\text { Cabang }\end{array}$ \\
\hline $\mathrm{P} 1: \mathrm{P}_{1}$ vs $\mathrm{P}_{2} \& \mathrm{P}_{3}$ & tn & tn & tn & $*$ & tn & tn & tn \\
\hline $\mathrm{P} 2: \mathrm{P}_{2}$ vs $\mathrm{P}_{3}$ & tn & tn & tn & $*$ & tn & tn & tn \\
\hline
\end{tabular}

Tabel 3. Rekapitulasi hasil uji orthogonal kontras pada variabel fase generatif pengaruh penggunaan Paklobutrazol, $\mathrm{KNO}_{3}$, dan Etefon pada pemacuan pembungaan tanaman manggis umur 29 minggu setelah aplikasi.

\begin{tabular}{lcc}
\hline & & Variabel Pengamatan \\
\cline { 2 - 3 } Perbandingan & Waktu & $\sum$ Buah \\
& Muncul & Per cabang \\
& Bunga & Sampel \\
\hline $\mathrm{P} 1: \mathrm{P}_{1}$ vs $\mathrm{P}_{2}$ & $*$ & tn \\
$\mathrm{P} 2: \mathrm{P}_{2}$ vs $\mathrm{P}_{3}$ & $*$ & $*$ \\
\hline
\end{tabular}

Keterangan: $\mathrm{P}_{1}=$ pupuk kandang $+\mathrm{NPK}, \mathrm{P}_{2}=$ pupuk kandang $+\mathrm{NPK}+$ Paklobutrazol $+\mathrm{KNO}_{3}, \mathrm{P}_{3}=$ pupuk kandang $+\mathrm{NPK}+$ Paklobutrazol + Etefon, $\mathrm{tn}=$ tidak berbeda nyata pada taraf $5 \%, *$ $=$ berbeda nyata pada taraf $5 \%$

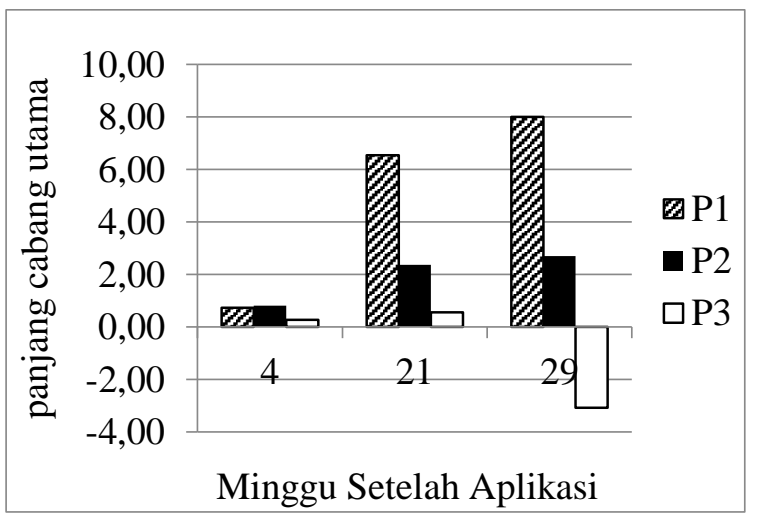

Gambar 1. Penambahan panjang cabang utama tanaman manggis 0-29 msa

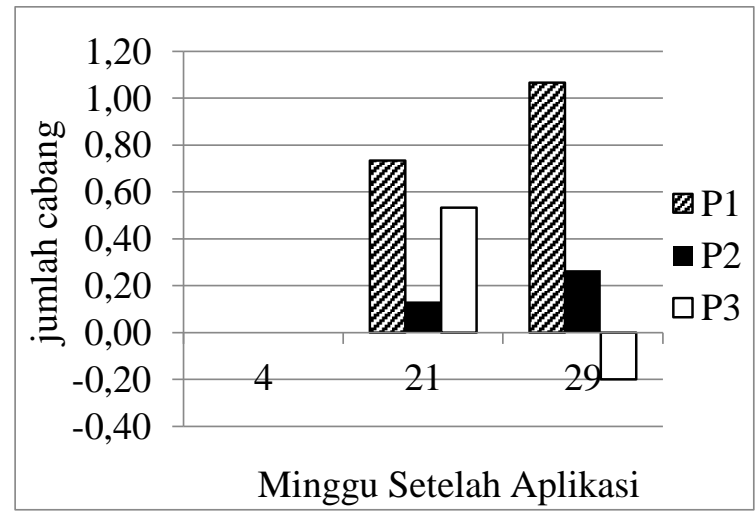

Gambar 2. Penambahan jumlah cabang tanaman manggis 0-29 msa 


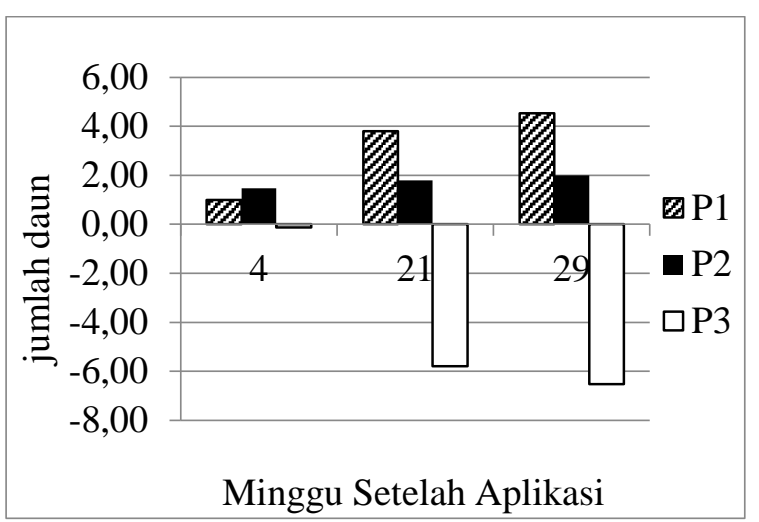

Gambar 3. Penambahan jumlah daun tanaman manggis 0-29 msa

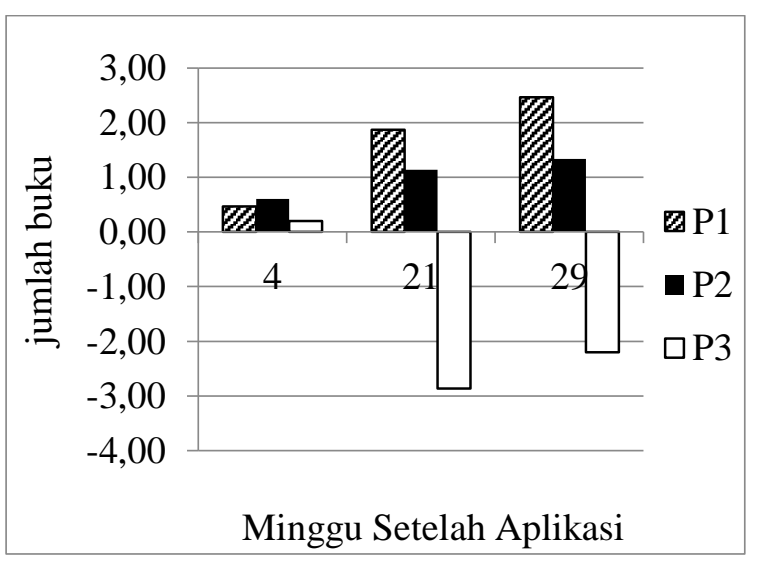

Gambar 4. Penambahan jumlah buku tanaman manggis 0-29 msa

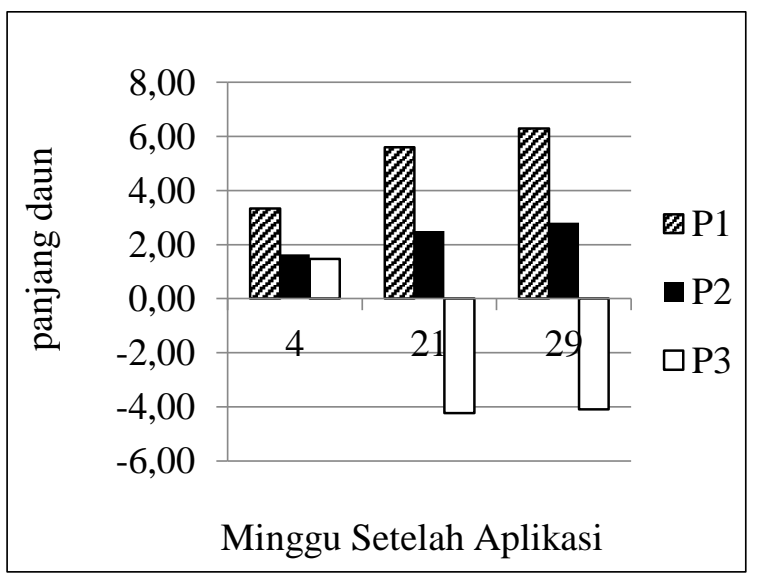

Gambar 5. Penambahan panjang daun tanaman manggis 0-29 msa

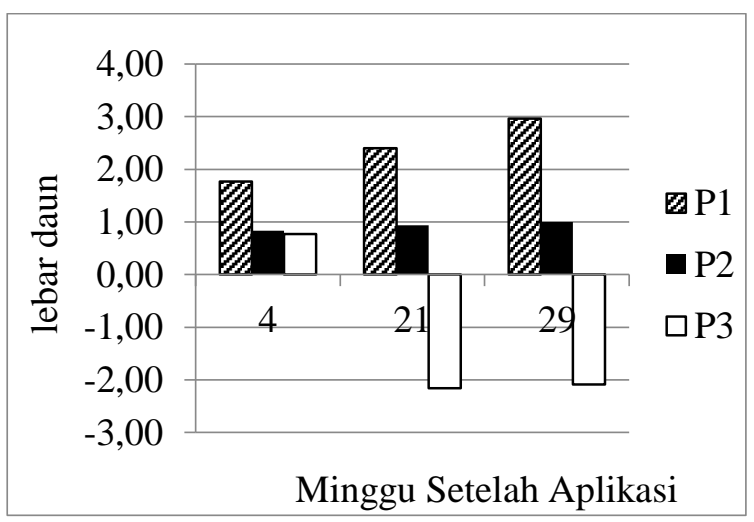

Gambar 6. Penambahan lebar daun tanaman manggis 0-29 msa

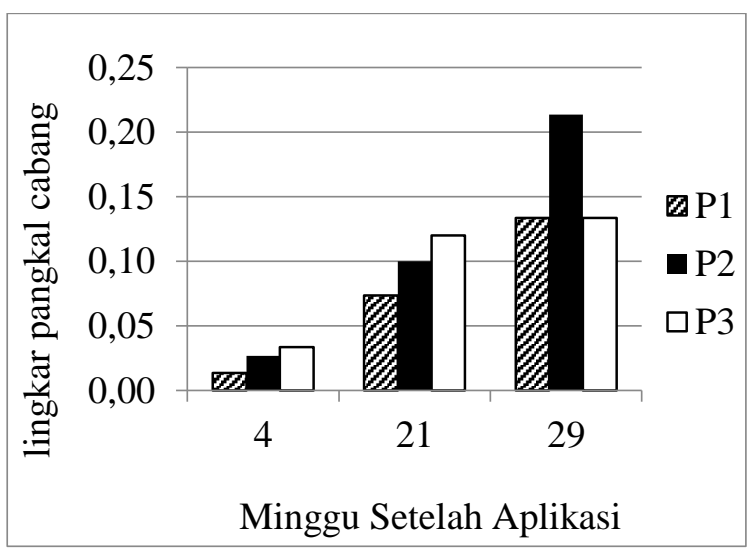

Gambar 7. Penambahan lingkar pangkal cabang tanaman manggis 0-29 msa

\section{Fase Generatif}

Tanaman manggis membutuhkan periode kering untuk menginduksi pembungaan. Menurut hasil penelitian Apiratikorn et al. (2012) tanaman manggis di Thaliand membutuhkan periode kering sekitar 21 hari untuk untuk merangsang bunga dan diikuti oleh irigasi atau curah hujan. Namun, pada saat penelitian ini berlangsung pada bulan September 2018April 2019 intensitas curah hujan sangat tinggi terutama pada bulan November yaitu $846 \mathrm{~mm}$, sehingga induksi pembungaan manggis terhambat. Periode berbuah mulai terjadi di bulan April 2019 dengan intensitas curah hujan yaitu $195 \mathrm{~mm}$ (Tabel 4). 
Tabel 4. Data curah hujan bulanan (mm) di Kota Agung Timur

\begin{tabular}{|c|c|c|c|c|}
\hline \multicolumn{3}{|c|}{2018} & \multicolumn{2}{|c|}{2019} \\
\hline \multirow{4}{*}{\multicolumn{2}{|c|}{$\begin{array}{l}\text { September } \\
\text { Oktober } \\
\text { November } \\
\text { Desember }\end{array}$}} & 109,0 & Januari & 229,0 \\
\hline & & 405,5 & Februari & 209,0 \\
\hline & & 846,0 & Maret & - \\
\hline & & 209,0 & April & 195,3 \\
\hline \multirow{9}{*}{ 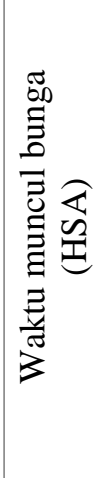 } & 160 & & & \multirow{9}{*}{$\begin{array}{l}\square \mathrm{P} 1 \\
\square \mathrm{P} 2 \\
\square \mathrm{P} 3\end{array}$} \\
\hline & 140 & & & \\
\hline & 120 & & & \\
\hline & 100 & & & \\
\hline & $\begin{array}{l}80 \\
60\end{array}$ & & & \\
\hline & 40 & & & \\
\hline & 20 & & & \\
\hline & & P1 & P2 & \\
\hline & \multicolumn{3}{|c|}{ Perlakuan } & \\
\hline
\end{tabular}

Gambar 8. Waktu muncul bunga tanaman manggis 0-29 msa

Hasil penelitian menunjukkan bahwa perlakuan Paklobutrazol dan $\mathrm{KNO}_{3}$ pada tanaman manggis nyata mempercepat waktu muncul bunga 138,00 hsa (hari setelah aplikasi) dibandingkan tanpa Paklobutrazol 150,00 hsa (Gambar 8). Hal ini sesuai hasil penelitian Sumantra et al. (2010) pada tanaman manggis yang diberi perlakuan Paklobutrazol 2 g, Etefon 400 ppm, Greener $2 \mathrm{ml} / \mathrm{l}$, pupuk kandang $10 \mathrm{~kg} /$ pohon, dan NPK $2 \mathrm{~kg} /$ pohon mampu mempercepat waktu muncul bunga yaitu 52 hsa dibandingkan dengan perlakuan pupuk kandang $10 \mathrm{~kg} /$ pohon dan NPK $2 \mathrm{~kg} /$ pohon yaitu 93 hsa. Hasil serupa juga dijumpai pada perlakuan Paklobutrazol dan $\mathrm{KNO}_{3}$ nyata meningkatkan jumlah buah per cabang sampel dibandingkan tanpa Paklobutrazol dan $\mathrm{KNO}_{3}$ (Gambar 9). Hal ini sesuai hasil penelitian Sumantra et al. (2010), bahwa pada tanaman manggis yang diberi perlakuan Paklobutrazol $2 \mathrm{~g} /$ tanaman dan $\mathrm{KNO}_{3}$ disertai penambahan pupuk kandang $10 \mathrm{~kg} /$ tanaman serta NPK $2 \mathrm{~kg} /$ tanaman mampu meningkatkan jumlah buah percabang sampel 18,86 buah dibandingkan dengan pemberian pupuk kandang 10 $\mathrm{kg} / \mathrm{tanaman}$ dan NPK $2 \mathrm{~kg} /$ tanaman yaitu 9,53 buah.

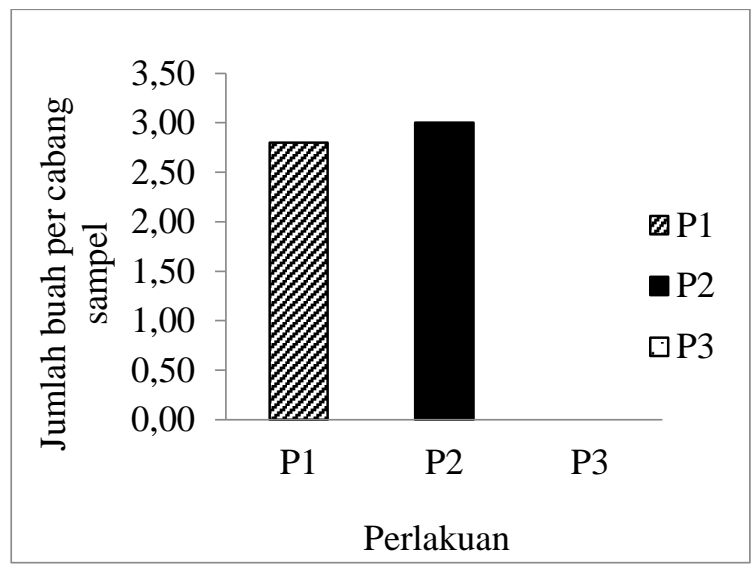

Gambar 9. Jumlah buah per cabang sampel

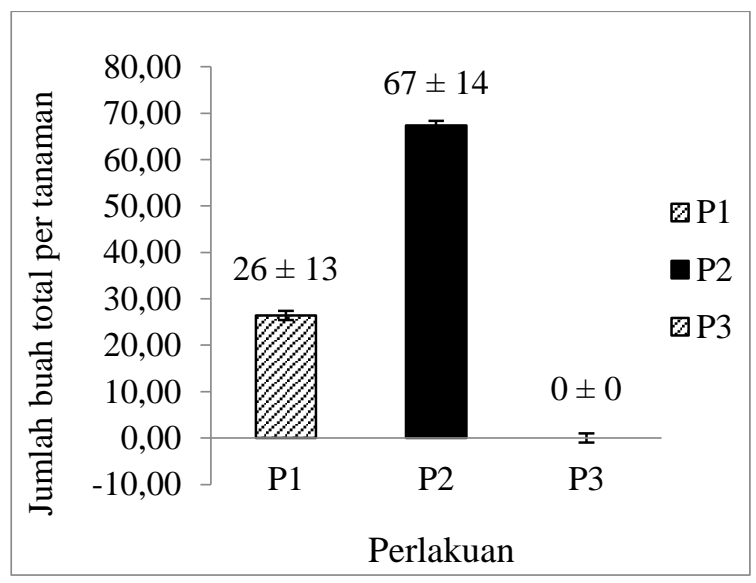

Gambar 10. Jumlah buah total per tanaman

Perlakuan Paklobutrazol disertai Etefon mengalami kerontokan daun setelah 21 sampai 29 minggu setelah aplikasi (msa). Daun merupakan sumber cadangan makanan untuk proses pembungaan sehingga menyebabkan tanaman manggis tidak muncul bunga dan tidak mampu berbuah. Menurut Moore (1979), Etefon dalam jaringan tanaman terhidrolisis menghasilkan etilen, ion klor, dan fosfat. Etilen selain berfungsi mendorong pemecahan dormansi tunas, juga mendorong terjadinya absisi. Pada penelitian ini diduga etilen yang digunakan jumlahnya terlalu banyak sehingga dampaknya lebih ke arah terjadinya absisi daun dibandingkan untuk 
pemecahan dormansi tunas generatif. Oleh karena itu hasil penelitian ini berbeda dengan hasil penelitian Rai et al. (2004) yang melaporkan bahwa perlakuan Paklobutrazol $2 \mathrm{~g} /$ pohon yang diikuti dengan pemberian Etefon $400 \mathrm{ppm}$ dapat meningkatkan jumlah bunga, jumlah buah panen, dan bobot buah per pohon pada tanaman manggis.

\section{KESIMPULAN}

Hasil penelitian menunjukkan bahwa perlakuan $\mathrm{P}_{2}$ (Paklobutrazol $2 \mathrm{ml} / \mathrm{L}+\mathrm{KNO}_{3}$ $20 \mathrm{~g} / \mathrm{L}+$ pupuk kandang $10 \mathrm{~kg} /$ tanaman + NPK $1 \mathrm{~kg} /$ tanaman) pada tanaman manggis, dapat mempercepat pembungaan dengan selisih 12 hari $(8,70 \%)$, dan meningkatkan jumlah buah per pohon dengan selisih 41 buah $(38,80 \%)$. Perlakuan $\mathrm{P}_{3}$ (Paklobutrazol $2 \mathrm{ml} / \mathrm{L}+$ Etefon $40 \mathrm{ml} / \mathrm{L}+$ pupuk kandang $10 \mathrm{~kg} /$ tanaman + NPK 1 $\mathrm{kg} / \mathrm{tanaman}$ ) menyebabkan tanaman mengalami kerontokan pada daun sehingga tidak terjadi pembungaan hingga 29 minggu setelah aplikasi.

\section{DAFTAR PUSTAKA}

Apiratikorn, S., Sdoodee, S., Lerslerwong, L., dan Rongsawat, S. 2012. The impact of climatic variability on phenological change, yield and fruit quality of mangosteen in Phatthalung Province, Southern Thailand. Kasetsart J. (Nat. Sci.) 46:1-9.

Bowo, B.T. 2018. Pengaruh Pemberian Pupuk Organik Cair (POC) Urin kambing dan Hormon Paclobutrazol terhadap Pertumbuhan Jambu Air Madu Deli (Syzgium aqueum Burn.F). Skripsi. Universitas Muhammadiyah Sumatera Utara. Medan. $50 \mathrm{p}$.

Darmawan, M. 2014. Induksi Pembungaan di Luar Musim pada Tanaman Jeruk Keprok (Citrus reticulata). Skripsi. Institut Pertanian Bogor. Bogor. 48 p.

Davies, P.J. 1995. The Plant Hormone Concept: Concentration, Sensitivity And Transport.
In: Davies PJ. (eds) Plant Hormone. Physiology, biochemistry and molecular biology $2^{\text {th }}$ edition. Kluwer Academic Publishers. Netherlands. Pp 13-38.

Dennis, F.P. and Neilsen, J.C. 1999. Physiological factors affecting biennial bearing in tree fruit: The role off seed in apple. Hort. Technology, 9(3):317-312.

Lakitan. 2011. Dasar-dasar Fisiologi Tumbuhan. Raja Grafindo Persada. Jakarta. 222 p.

Lingga, P., dan Marsono. 2011. Petunjuk Penggunaan Pupuk. Penebar Swadaya. Jakarta. $21 \mathrm{p}$.

Lolaei, A., Mobasheri, S., Bemana, R., dan Teymori, N. 2013. Role of paclobutrazol on vegetative and sexual growth of plants. J. Agric. 5(9):958-961.

Maloba, S., Jane, A., Margaret, H., and Willis, O. 2017. Off-season flower induction in mango fruits using ethepon and potassium nitrate. J. Of Agric. Sci. 9(9):158-167.

Moore, T.C. 1979. Biochemistry and Physiology of Plant Hormones. SpringerVerlag Inc. New York. 101 p.

Ounlert, P., Sayan, S., dan Pitsanu, T. 2017. The mangosteen flowering date model in Nakhon Si Thammarat province, southern Thailand. J. Of Central European Agric. 18(1):176-184.

Paramawati, R. 2010. Dahsyatnya Manggis untuk Menumpas Penyakit. Agromedia Pustaka. Jakarta. 102 p.

Poerwanto, R., Effendi, D., dan Haryadi, S.S. 1997. Pengaturan pembungaan mangga Gadung 21 di luar musim dengan paklobutrazol dan zat pemecah dormansi. Jurnal Hayati, 4(2):41-46.

Rai, I.N., Poerwanto, R., Darusman, L.K., dan Purwoko, B.S. 2004. Pengaturan pembungaan pohon manggis (Garcinia mangostana L.) di luar musim dengan strangulasi, serta aplikasi paklobutrazol dan etepon. Bul. Agron. 32(2): 12-20.

Rukmana, R. 1995. Budidaya Manggis (Garcinia mangostana L.). Kanisius. Yogyakarta. 57 p. 
Sakhidin dan Suparto, S.R. 2011. Kandungan giberelin, kinetin, dan asam absisat pada tanaman durian yang diberi paklobutrazol dan etepon. J. Hort. Indonesia, 2(1):2126.

Sumantra, I. K., Wiswasta, IGN. A., Sujana, I. P., dan Widynyana, I. K. 2010. Peningkatan produksi dan pendapatan petani manggis melalui penerapan teknologi pembuahan manggis di luar musim di Selemadeg, Tabanan. Majalah Aplikasi Ipteks Ngayah, 1(1):71-80. 